\title{
ФИЛОСОФИЯ
}

DOI: 10.17805/ggz.2018.3.7

\section{Перспективы гуманитарных наук в контексте развития технологий будущего}

О. В. Попова

Институт философии РАН

В статье представлен анализ тенденций современного гуманитарного знания в контексте развития технологической среды и появления технологических инновачий, вызывающих различные антропологические риски.

Рассмотрен разработанный М. Эпштейном проект создания междисциплинарного Центра гуманитарных инноваций в Великобритании, который занимается осмыслением и формированием будущего гуманитарных наук. Продемонстрирован его техноцентричный характер, в контексте которого человеку отводится роль инструмента, объекта технологических воздействий. В контексте современных тенденций развития технологий формируются новые очертания гуманитарного знания, своего рода постгуманитаристика, техногуманистики (М. Эпштейн), исследующей тексты, творения, а также место и следы в истории и современности человека технологического (homo technologicus), сформированного современным пространством киберкультуры.

Кроме того, в статье показана альтернатива этому проекту - деятельность в 1990-х - начало 2000-х гг. Института человека РАН, связанная с именами И. Т. Фролова и Б. Г. Юдина, исследования которых были направлены на комплексное изучение человека и формирование гуманитарного знания с использованием методологии гуманитарной экспертизы, позволяющей осуществить оперативное реагирование на технологические угрозы, прочувствовать и минимизировать технологические риски.

Ключевые слова: гуманитарные науки; будущее; гуманитарная экспертиза; постгуманитаристика; техногуманистика; антропологические риски

\section{Prospects for the Humanities in the Context of the Development of Future Technologies \\ O. V. Popova \\ Institute of Philosophy, Russian Academy of Sciences}


The article presents an analysis of trends in contemporary humanities knowledge in the context of the development of technological environment and the emergence of technological innovations that cause various anthropological risks.

The author examines M. Epshtein's project of creating the interdisciplinary Center for Humanities Innovations in Great Britain, which is engaged in comprehension and shaping of the future of the humanities. This project demonstrates its technocentric nature, in the context of which the human being is given the role of an instrument, an object of technological influences. In the context of modern trends in technology development, new outlines of humanities knowledge are emerging, a kind of posthumanities, techno-humanities (M. Epshtein), exploring texts, creations, as well as the place and traces in history and modernity of the technological man (homo technologicus) who is formed by contemporary space of cyberculture.

In addition, the article shows an alternative to this project - the activities of the Institute of Human Sciences of the Russian Academy of Sciences in the 1990s and early 2000s, associated with the names of I. T. Frolov and B. G. Yudin, whose research was aimed at a comprehensive study of man and the formation of humanities knowledge using the methodology of expert evaluation in the humanities, allowing a rapid response to technological threats in order to experience and minimize technological risks.

Keywords: humanities; future; expert evaluation in the humanities; posthumanities; techno-humanities; anthropological risks

\section{ВВЕДЕНИЕ}

Перспективы современного развития гуманитарного знания в ведущих странах мира неразрывно связаны с поиском способа реагирования, «ответа» гуманитарных дисциплин на развитие технологической среды, на появление инноваций, несущих значительные гуманитарные риски.

Гуманитаристика имеет дело, с одной стороны, с неповторимостью человеческого бытия, с его уникальностью, однако, с другой, опирается на базис представлений о природе человека, на своего рода антропологические константы. Безусловно, эти константы подвержены изменению в различные культурно-исторические эпохи, однако сам процесс этого изменения, как правило, происходит спонтанно. Сейчас же мы имеем дело с ситуацией, когда этот базис (природа человека) открыт экспериментированию, намеренному рациональному конструированию. И намеренное вторжение в биологические основания личности, вызывающее их модификацию, в частности, радикальное усиление или преобразование тех или иных антропологических характеристик, позволяет предположить, что мы будем иметь дело с другой гуманитаристикой, со своего рода постгуманитаристикой, исследующей тек- 
сты, творения, а также место и следы в истории и современности уже не человека, а постчеловека, отличающегося от нас как образом своего бытия, так и образом своего мышления, иной конфигурацией телесности - все сильнее уподобляющейся артефакту.

В современных исследованиях социальных процессов все чаще предметом рассмотрения становится не человек, а вещь. Например, социальное рассматривается сквозь призму отношения человека к артефакту, соотношения артефактов между собой на основании сетевого принципа и т. д. В основании подобного подхода лежит идея Б. Латура о том, что артефакты не просто отражают социальное, но составляют его субстрат (Латур, 2014). Поворот от человека к вещи, артефакту - не случаен. Такого рода «вещизм» олицетворяет предвестие новых форм существования социального, где артефакты постепенно будут завоевывать все более значимые позиции, где, возможно, и сам человек будет понят и задан, спроектирован как артефакт. И проблема здесь, безусловно, не ограничивается представлением о человеке как социальном артефакте, на который наносит свои знаки общество и культура, но прежде всего речь идет о конструировании нового типа человека, неестественного по своей природе не в результате пребывания в мире культуры, а до своего пребывания в мире вообще, до своего зачатия и усложняющегося в своей артефактичности в своем дальнейшем существовании, обретая искусственные улучшенные части тела, вживляя когнитивные усилители и поглощая какие-нибудь препараты для модификации своих чувств и контроля настроения.

Такого рода человек постепенно становится предметом новой озабоченности гуманитарных наук и определенным вызовом, заставляющим взглянуть по-новому на процесс демаркации границ между природой и культурой, и, очевидно, провоцирующим ситуацию, когда, столкнувшись с ним, впору будет заявить об отсутствии у него природы.

В настоящее время подобные утверждения звучат алармистски, фантастически, однако и сама фантастика все чаще заявляет о себе как предмет особо пристального внимания со стороны гуманитариев. В ней заложен мощный трансформативный потенциал, поддерживаемый невероятными темпами научно-технического прогресса. Весь цикл гуманитарных дисциплин постепенно вовлекается в осмысление фантастических перспектив будущего, кардинально меняющего нас самих, изменяющего постановку вопроса о человеке.

\section{ЦЕНТР ГУМАНИТАРНЫХ ИННОВАЦИЙ}

В этой связи интересной представляется создание М. Эпштейном междисциплинарного Центра гуманитарных инноваций в Великобритании, кото- 
рый занимается осмыслением и формированием будущего гуманитарных наук. Задачи этого центра направлены на преобразование предметного поля гуманитаристики, создание новых фантастических дисциплин и новых гуманитарных технологий.

Сама идея подобного института возникла у философа в процессе осознания кризиса гуманитарных наук. Как отмечает М. Эпштейн, в XX в. гуманитарные науки отворачиваются «от своего предмета - человека, переключившись на изучение текстов, впав в интеллектуальный аутизм и утратив интерес к людям как существам духовным и творческим? <..> Гуманистика стала текстологией и перестала быть человековедением. B XVIII-XIX веках гуманитарные дисциплины: метафизика, логика, политическая и социальная философия, философия религии, этика, эстетика, история, психология, филология, искусствознание и литературоведение, культурная и художественная критика, языкознание - были науками именно о человеке и человечестве, а не о текстах, какой гуманистика стала к концу XX века» (Эпштейн, 2016: 18; курсив источника. - О. П.). М. Эпштейн вводит понятие «техногуманистика», дисциплины, направленной на изучение радикальных изменений человека и модификацию его природы перед лицом новейших технологий. Речь идет не только об описании оказывающих влияние на человека происходящих технологических изменений, по прежде всего об активном соучастии гуманитариев в приближении постчеловеческого будущего. В либеральном проекте М. Эпштейна теоретическое исследование технологического преобразования человека и изучение влияния информационных технологий на гуманитарную сферу знаний и ее методологию идет бок о бок с созданием «искусственного интеллекта в гуманистической перспективе», формированием «новой интеллектуальной среды, ИнтеЛнета, создания экспериментальных знаковых конфигураций, воплощающих новые возможности гуманитарного творчества и проектирования» (там же: 40).

М. Эпштейн, описывая особенности развития современной науки, обозначает переход от “science fiction” к “fiction science” (Будущее гуманитарных наук, 2012: Электронный ресурс), от научной фантастики к фантастической науке. Он вызван необычайно динамичным технологическим развитием, когда скорость появления инноваций и их разнообразие поражает самое сильное воображение. Интенсивное развитие технологий запускает процесс самоопределения многих дисциплин гуманитарного цикла. Они вынуждены учитывать «фантастический» фон усложняющейся технологической реальности.

Следует отметить, что проект М. Эпштейна, реализуя технооптимистический сценарий развития современной гуманитаристики, имел свой российский аналог, правда, более консервативной направленности. Речь идет о созданном в 1991 г. Институте человека. 


\section{ИНСТИТУТ ЧЕЛОВЕКА}

Еще в 1986 г. академик И. Т. Фролов, обозначая контуры поля исследования будущего Института человека, выделил в качестве отдельного раздела проблему человека. По мнению ученого, феномен «человек» должен был быть исследован в рамках специальных наук. В частности, его волновали медицинские и биохимические аспекты изучения человека (Фролов, 2001). С другой стороны, И. Т. Фролов настаивал на комплексном, философском подходе к исследованию проблемы человека, который бы задавал более широкую перспективу, возвышающуюся над точками зрения отдельных дисциплин. Он оказался особенно актуален в контексте продолжающейся научнотехнической революции. Академик отстаивал целостное исследование человека, стремился к интеграции знаний о человеке с использованием достижений различных наук. Комплексный, междисциплинарный подход, заложенный в программу Института человека РАН, активно развивался его сотрудниками. Особое внимание уделялось методологии гуманитарной экспертизы. Согласно Б. Г. Юдину, который сменил И. Т. Фролова на посту директора Института человека РАН, гуманитарная экспертиза является творческой деятельностью по опережающему проживанию ситуаций, порождаемых прогрессом биомедицинских технологий, «оперативному реагированию» (Юдин, 2006) на угрозы человеческому потенциалу и их проактивному этикоантропологическому оформлению. В созданном в структуре Института человека секторе биоэтики «изучались этические и правовые аспекты современной генетики человека, новых технологий деторождения... клонирования...» (Белкина, Корсаков, 2009: 67).

Сравнение проектов создания Центра гуманитарных инноваций в Великобритании и существовавшего Института человека РАН демонстрирует их общую ориентацию на комплексное изучение человека в условиях технологически развивающегося мира и в целом наличие установки на развитие гуманитарного знания с учетом технологического уклада. В то же время существенные различия связаны с самим объектом исследования - человеком.

Если для основателя Института человека РАН И. Т. Фролова важным было как комплексное исследование человека, так и сохранение антропологических констант перед лицом технологических угроз, своего рода сохранение человеческого в человеке, то для директора Центра гуманитарных инноваций Даремского университета в 2012-2015 гг. М. Эпштейна наоборот ценным оказывается не неизменная сущность человека, а его способность к модификации, та черта, которая позволяет принять ему разные формы бытия, стать иночеловеком, постчеловеком. Защита человека оказывается защитой нечеловеческого, надприродно-технологического. Это та ситуация, о которой 
удачно выразился последний директор Института человека РАН Б. Г. Юдин: у человека «ядро поплыло» (Юдин, 2015: 190).

\section{ЗАКЛЮЧЕНИЕ}

Техноцентризм провоцирует изменения окружающей среды, но главным объектом этих изменений, мишенью технологий становится сам человек. Утрата внутренней экологии в процессе неуправляемого технологического развития становится неизбежной. Именно по этой причине человеку в его классическом понимании, в проекте М. Эпштейна, ничего не остается кроме как заселять особые зоны с остатками человеческого - антропопарки: «Вслед за природой, которая интегрируется в состав растущей всепланетной цивилизации, и человек будет все более восприниматься в модусе редкости, как замкнутый биоценоз, встроенный в более могущественную техническую среду. Функция человеческого, возможно, будет закрепляться за искусственно изолированными, охраняемыми территориями, “антропопарками”, вроде того, как природа в настоящем, “первозданном” виде уже сейчас существует за оградой искусственных заповедников» (Эпштейн, 2016: 128). И в этой связи, безусловно, особую актуальность приобретает гуманитарная экспертиза различных форм технологического воздействия н человека, позволяющая не потерять человека как главный предмет гуманитарных наук.

\section{СПИСОК ЛИТЕРАТУРЫ}

Белкина, Г. Л., Корсаков, С. Н. (2009) И. Т. Фролов и становление отечественной биоэтики // Биоэтика и гуманитарная экспертиза. Вып. 2. / отв. ред. Ф. Г. Майленова. М.: Институт философии РАН. 230, [2] с. С. 18-54.

Будущее гуманитарных наук (2012) : интервью / А. Генис, М. Эпштейн [Электронный ресурс] // Радио Свобода. 12 ноября. URL: http://www.svoboda.org/content/transcript/24769034.html [архивировано в WaybackMachine] (дата обращения 15.05.2018).

Латур, Б. (2014) Пересборка социального: введение в акторно-сетевую теорию / пер. с англ. И. Полонской ; под ред. С. Гавриленко ; Нац. исслед. унт «Высшая школа экономики». М. : Изд. дом Высшей школы экономики. 384 c.

Фролов, И. Т. (2001) На пути к единой науке о человеке // Академик Иван Тимофеевич Фролов : Очерки. Воспоминания. Материалы / отв. ред. В. С. Степин. М. : Наука. 644, [1] с. С. 491-503.

Эпштейн, М. Н. (2016) От знания — к творчеству. Как гуманитарные науки могут изменять мир. М. ; СПб. : Центр гуманитарных инициатив. 480 c.

Юдин, Б. Г. (2006) От этической экспертизы к экспертизе гуманитарной // Гуманитарное знание: тенденции развития в XXI веке. В честь 70- 
летия Игоря Михайловича Ильинского / колл. моногр. ; под общ. ред. Вал. А. Лукова. М. : Изд-во Нац. ин-та бизнеса. 680 с. С. 214-237.

Юдин, Б. Г. (2015) У человека было ядро... но и оно «поплыло» : интервью / Б. Г. Юдин, С. А. Смирнов (кор.) // Человек.Ru. № 10. С. 189-197.

Дата поступления: 20.05.2018 г.

Попова Ольга Владимировна - кандидат философских наук, ведущий научный сотрудник, руководитель сектора гуманитарных экспертиз и биоэтики Института философии Российской академии наук. Адрес: 109240, Россия, г. Москва, ул. Гончарная, д. 12, стр. 1. Тел.: +7 (495) 697-91-09. Эл. адpec: J-9101980@yandex.ru

Popova Olga Vladimirovna, Candidate of Philosophy, Leading Researcher, Head of Department of Humanitarian Expertise and Bioethics, Institute of Philosophy, Russian Academy of Sciences. Postal address: Bldg. 1, Goncharnaya St., 12, 109240 Moscow, Russian Federation. Tel.: +7 (495) 697-91-09. E-mail: J-9101980@yandex.ru

Для цитирования:

Попова O. В. Перспективы гуманитарных наук в контексте развития технологий будущего [Электронный ресурс] // Горизонты гуманитарного знания. 2018. № 3. С. 103-109. URL: http://journals.mosgu.ru/ggz/article/ view/801 (дата обращения: дд.мм.гггг). DOI:10.17805/ggz.2018.3.7 